\title{
Specificity of diatom communities attached on the carapace of the European pond turtle (Emys orbicularis)
}

\author{
Vincent Roubeix, ${ }^{1 *}$ Lucie Attia, ${ }^{2}$ Rémy Chavaux, ${ }^{3}$ Franck Very, ${ }^{4}$ Anthony Olivier,,${ }^{5}$ Luc Ector, ${ }^{6}$ Véronique Vassal ${ }^{7}$ \\ ${ }^{1}$ HydroBioStat, Aix-en-Provence, France; ${ }^{2}$ DREAL Occitanie, Laboratoire d'Hydrobiologie, Cité administrative - Bât G, 1 rue de la \\ Cité Administrative, CS 8002, 31074 Toulouse Cedex 9, France; ${ }^{3}$ DREAL Auvergne-Rhône-Alpes, Laboratoire d'Hydrobiologie, 5 \\ Place Jules Ferry, 69453 Lyon Cedex 06, France; ${ }^{4}$ DREAL Auvergne-Rhône-Alpes, Laboratoire d'Hydrobiologie, 7 Rue Léo Lagrange, \\ 63000 Clermont-Ferrand, France; ${ }^{5}$ La Tour du Valat, Institut de Recherche pour la Conservation des Zones Humides Méditerranéennes, \\ Le Sambuc, 13200 Arles, France; ${ }^{6}$ Environmental Research and Innovation (ERIN) Department, Luxembourg Institute of Science and \\ Technology (LIST), 41 rue du Brill, 4422 Belvaux, Luxembourg; ${ }^{7}$ DREAL PACA, Laboratoire d'Hydrobiologie, Pôle d'activités Les \\ Milles, Avenue Albert Einstein, Bâtiment E Cerema, Dter med 13593m, CS 70499, 13593 Aix-en-Provence Cedex 3, France
}

\section{ABSTRACT}

Periphytic diatoms growing on aquatic turtle carapaces provide an interesting example of biofouling on an animal substrate. This study dealt with the question of the specificity of epizoic diatom communities for the case of the European pond turtle (Emys orbicularis), across five water bodies in South-Eastern France; 375 diatom taxa have been identified on the European pond turtle carapace. The results showed that the epizoic communities of the five sites were significantly different from each other. The epizoic diatom communities could be clearly distinguished from epilithic and epiphytic communities only in two out of five sites. The differences in composition at the two sites resulted from the greater abundance of some species and life forms. However, the characteristic pattern of diatom communities on the carapaces was not the same at the two sites. It therefore appeared that the European pond turtle's carapace did not harbour specific diatom communities and can rather be considered a neutral substrate.

\section{INTRODUCTION}

Any submerged surface exposed to light is likely to be colonized by more or less adherent benthic phototrophic organisms. The carapace of turtles living in aquatic environments is no exception. Herpetologists and algologists have long been interested in algal species living as epibionts on freshwater and marine turtles (basibionts) (Edgren et al., 1953). The relationship between turtle and algae is considered commensal, since algae take advantage of the movement of their host for access to resources and dispersion, while algae generally have little effect on the health of their host (Edgren et al., 1953; Neil and Allen, 1954; Wahl, 2008). It can even be seen as a kind of mutualism because algae can provide camouflage for turtles against predators. The study of epibiosis in turtles has historically focused on macro-epibionts and especially macroalgae (Neil and Allen, 1954; Frick and Pfaller, 2013), while epizoic microalgae have only recently been investigated (Wu and Bergey, 2017).

Diatoms, because of their high adhesion capacity and rapid growth, are well-known early colonizers of submerged surfaces (Wahl, 1989; Biggs et al., 1998). Because of their ubiquitous nature and high specific diversity, benthic forms are widely used as biological indicators of water quality (Poulíčková and Manoylov, 2019). The last decade has seen a growing interest in diatoms on turtle shells (Wetzel et al., 2010; Majewska et al., 2015; Wu and Bergey, 2017; Donato et al., 2018; Vassal et al., 2020). It is possible to distinguish species-level studies focusing on the search for new taxa, probably specific to epizoic habitat (Wetzel et al., 2012; Majewska et al., 2020) and others at the level of diatom com- munities, focusing on variations observed at the host individual level, or between turtle populations or species (Fayolle et al., 2016; Robinson et al., 2016; Wu and Bergey, 2017). The purpose of the latter is sometimes to obtain information on the environments frequented by individuals (Vassal et al., 2020) and on their movements. Such information can be valuable considering that many turtle species are in danger of extinction (Rhodin et al., 2018).

However, the discovery of new species supposedly restricted to the epizoic habitat and the tracing of turtle movements by studying the communities present on their carapace are based on different hypotheses concerning the selectivity of the carapace substrate. In the first case, the carapace of the turtles is assumed to be highly selective so that new taxa discovered in this habitat are considered typically epizoic, thus forming part of the obligatory epibionts. In the second case, the epizoic flora is supposed to reflect the surrounding benthic communities in the turtle's living environment, with diatoms being seen as facultative epibionts (Wahl and Mark, 1999) and the turtle carapace as a neutral substrate (Blindow, 1987). In order to be able to determine whether turtle carapace is a neutral substrate or whether it selects a specific community, it is necessary to sample, at each study site, several host individuals and other types of substrates, such as stones or macrophytes, generally used for biofilm sampling in running waters and lakes. This has generally not been done formally in the above-mentioned studies on turtle-diatom relationships and yet it is the only way to characterize the specificity of diatom communities living on turtle carapaces.

The European pond turtle Emys orbicularis (Linnaeus 
1758 ) is a medium-sized freshwater turtle with a wide ecological range. Its home range size is limited by physical barriers which means that individuals can use the whole surface of a wetland with a preference for habitats with a strong plant density (Cadi et al., 2008). During its period of activity (generally from March to October), it comes out of the water for its thermoregulation needs (Di Trani and Zuffi, 1997) and for egg-laying by females (Rovero and Chelazzi, 1996). More rarely, individuals can migrate on land or estivate during droughts and low-water periods (Naulleau, 1992). Due to its significant decline, E. orbicularis benefits from a national action plan for protection in France (Thienpont, 2020) and is listed in Annexes II and IV of the EU Habitats Directive. Diatom species have already been recorded on the European pond turtle in Turkey, France and Serbia (Soylu et al., 2006; Akgul et al., 2014; Ersanli and Gonulol, 2014; Fayolle et al., 2016; Vidakovic et al., 2018), but the specificity of carapace communities in relation to other natural substrates has only recently been addressed (Vassal et al., 2020).

The suitability of diatoms collected on turtle carapace for water quality bioindication was assessed in two Mediterranean sites (Vassal et al., 2020). The investigation was extended in the present study by the inclusion of three other sites and a closer analysis of the specificity of diatom epizoic communities. Periphytic diatoms were sampled on three different types of substrates: on European pond turtle carapace, on stones and on macrophytes. For practical reasons related to the analysis of the data, the question of the specificity of the epizoic communities was divided into three sub-questions: i) Are the diatom communities of the European pond turtle carapace the same among sites? This is the question generally raised in large-scale epizoic community studies (Wu and Bergey, 2017) and a similarity of communities sampled at different sites may suggest that the epizoic flora is specific; ii) Are there typical species of the epizoic habitat? This is the question that generally interests taxonomists and implies a selection of specific taxa more adapted to the habitat, as a result of a co-evolution of host and epibiont species; iii) At each site, what are the differences between epizoic communities and those of other substrates? This third sub-question investigates whether epizoic diatom communities are representative of the periphytic communities at a given site and similar to those commonly sampled on stones or plants. Substrate neutrality implies no significant species selection, but does not preclude variation in community density, which depends on various factors related to the host and its environment (Frick and Pfaller, 2013). For this reason, the study focused only on community composition and relative abundance. The investigation was carried out through two scales of space (inter-sites and intra-site) and two levels of biological organization (community and species).

\section{METHODS}

\section{Periphytic biofilm sampling}

Periphytic diatoms were sampled in five French water bodies of various types, hereafter identified by their code (Ver, Sav, Esq, Cha, Tar), where populations of the European Pond Turtle are present and monitored (Fig. 1, Tab. 1). All sampling sites are small or medium lentic systems: one is brackish (Tar) and another is eutrophic with low $\mathrm{O}_{2}$ concentration (Cha). At sites Cha, Esq and Tar, where no mineral substrate was available, pebbles collected on the shore of the lakes were placed in a permanently submerged area at least one month prior to sampling. At each site epilithic biofilm was collected from at least five pebbles and mixed to form an integrated sample. Similarly, epiphytic biofilm was collected from at least five stems of helophytes present in the water body and mixed. The sampling of epilithic and epiphytic diatoms followed the national protocol defined for bioindication in water bodies (Irstea, 2013). The turtles were captured by hand or with fyke nets. The epizoic biofilm was obtained by brushing with a toothbrush an area of 20 $\mathrm{cm}^{2}$ on the back of the carapace of ten adult turtle individuals (only seven for the Ver site where no more individuals could be captured) (Fig. 2). The biofilm on the carapaces was generally very thin, even invisible, and no macrophyte was apparent on the sampled area. Collection from each individual provided one epizoic sample. Analytical effort was concentrated on the animal substrate that is least known, so that site-specific replicates were considered only for epizoic communities. In order to facilitate comparison between substrates within a site, an additional integrated sample was prepared by mixing subsamples of all singular epizoic samples. Thus, the number of samples per site was 13 in total (10 for site Ver). For each site, the sampling of the three substrate types was done within $24 \mathrm{~h}$, in spring or early summer (Tab. 1), assuming little temporal variations in differences of periphytic communities among substrate types over the months of sampling. Samples were fixed in $90 \%$ ethanol until preparation for analysis.

\section{Sample preparation and diatom counts}

The samples were digested in hot hydrogen peroxide $\left(90^{\circ} \mathrm{C}\right)$ for several hours and then treated with concentrated hydrochloric acid. After rinsing and decanting, they were mounted on microscope slides and fixed with Naphrax ${ }^{\circledR}$ before being observed under an optical microscope. At least 400 diatom valves were counted in each sample. The species were identified according to the specific literature (Lange-Bertalot et al., 2017). The determination of certain difficult taxa required examination with a scanning electron microscope. 


\section{Data analysis}

The analysis of abundance data of diatom species in periphytic communities was carried out using R software and the vegan and labdsv packages (Oksanen et al., 2019; Roberts, 2019). Only species with a maximal relative abundance exceeding $1 \%$ were considered in the statistical treatments on communities.

As species abundance in communities do not comply with the hypothesis of multinormality, standard parametric tests could not be applied. Therefore, the similarity of epizoic communities between sites was tested using nonparametric multivariate analysis of variance (NP Manova, Anderson, 2001) with Canberra distance on untransformed relative abundance data $(n=47,9999$ permutations). The homogeneity of community variance between sites was previously tested and found to be acceptable (anova; $\mathrm{p}=0.16$ ). The samples were represented on a plot by principal coordinate analysis ( $\mathrm{PCoA}$ ) using the same Canberra distance. The NP Manova was then repeated ten times to compare epizoic communities between each pair

Table 1. Synthetic data about the five study sites ( $\mathrm{nd}=$ not determined).

\begin{tabular}{|c|c|c|c|c|c|c|c|c|c|c|}
\hline Code & Name & Location & $\begin{array}{l}\text { Geographic } \\
\text { coordinates }\end{array}$ & $\begin{array}{c}\text { Type of water } \\
\text { body }\end{array}$ & $\begin{array}{l}\text { Sampling } \\
\text { date }\end{array}$ & $\begin{array}{c}\text { Macrophytes } \\
\text { used for } \\
\text { sampling }\end{array}$ & $\begin{array}{l}\text { Temp. } \\
\left({ }^{\circ} \mathrm{C}\right)\end{array}$ & $\mathrm{pH}$ & $\begin{array}{l}\text { Cond. } \\
(\mu \mathrm{S} / \mathrm{cm})\end{array}$ & $\begin{array}{c}\mathrm{O}_{2} \\
(\mathrm{mg} / \mathrm{L})\end{array}$ \\
\hline Ver & Verrerie & Thionne & $\begin{array}{c}46.419450^{\circ} \mathrm{N} \\
3.561080^{\circ} \mathrm{E}\end{array}$ & Shallow lake & $06 / 21 / 2018$ & Juncus sp. & 27.8 & 6.9 & 30 & 8.6 \\
\hline Sav & Save & Arandon-Passins & $\begin{array}{c}45.703177^{\circ} \mathrm{N} \\
5.452998^{\circ} \mathrm{E}\end{array}$ & Lake & $04 / 24 / 2018$ & Carex sp. & 19.9 & 7.7 & 564 & 9.1 \\
\hline Esq & Esquineau & Arles & $\begin{array}{c}43.509970^{\circ} \mathrm{N} \\
4.655926^{\circ} \mathrm{E}\end{array}$ & Marshes & $06 / 08 / 2017$ & $\begin{array}{c}\text { Phragmites } \\
\text { australis }\end{array}$ & 26.2 & 7.8 & 459 & 6.47 \\
\hline Cha & Charpines & La Roque d'Anthéron & $\begin{array}{c}43.734896^{\circ} \mathrm{N} \\
5.313876^{\circ} \mathrm{E}\end{array}$ & $\begin{array}{l}\text { Oxbow of } \\
\text { the Durance } \\
\text { River }\end{array}$ & $06 / 29 / 2016$ & $\begin{array}{c}\text { Phragmites } \\
\text { australis }\end{array}$ & 26 & nd & 1360 & 4 \\
\hline Tar & Tartuguière & Lansargues & $\begin{array}{c}43.628857^{\circ} \mathrm{N} \\
4.094122^{\circ} \mathrm{E}\end{array}$ & $\begin{array}{l}\text { Brackish } \\
\text { marshes }\end{array}$ & $05 / 15 / 2018$ & $\begin{array}{c}\text { Phragmites } \\
\text { australis }\end{array}$ & 13.8 & 8 & 9110 & nd \\
\hline
\end{tabular}

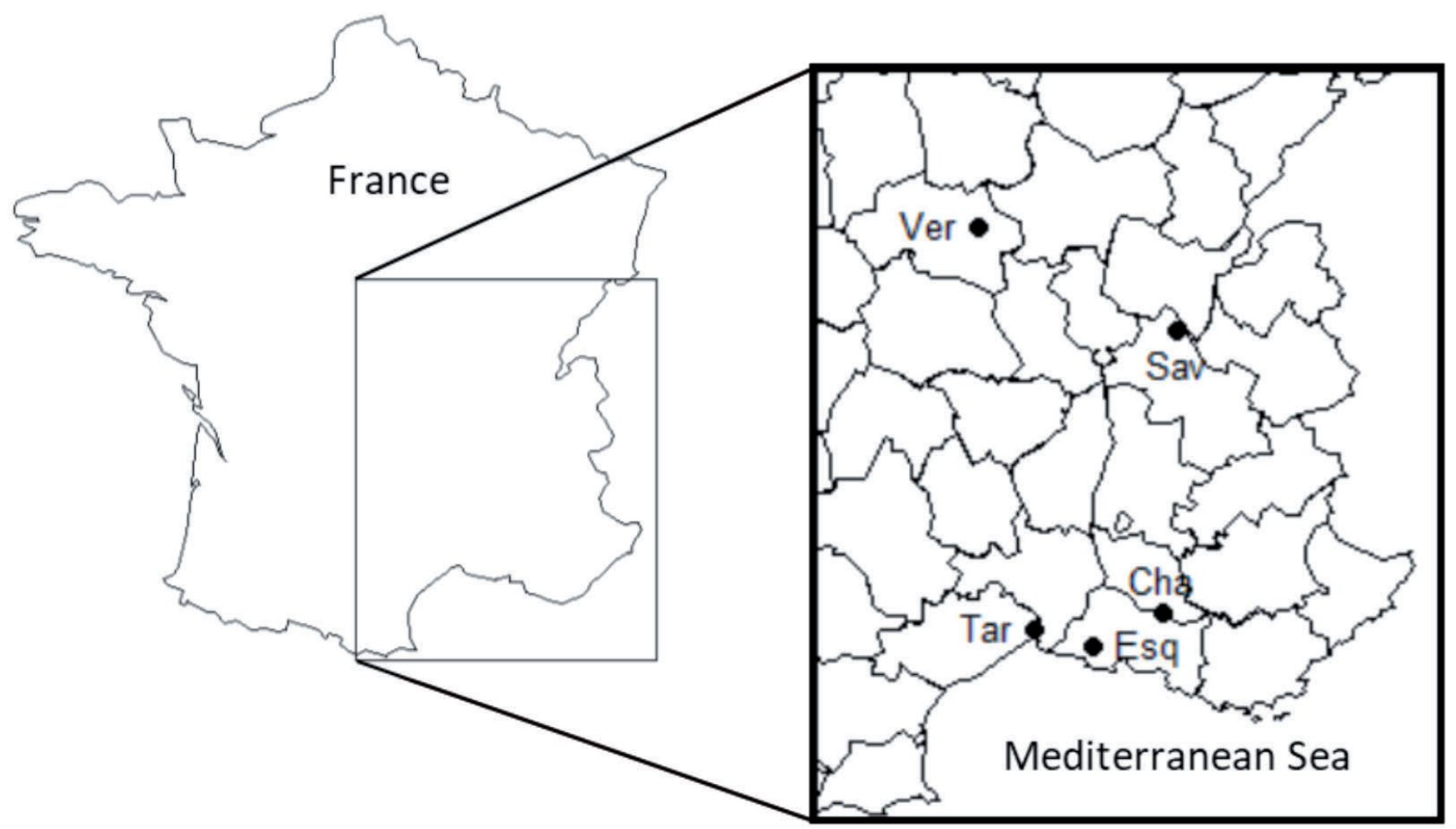

Fig. 1. Location of the five study sites. 
of sites. Shannon diversity and species richness of samples were compared among sites and type of substrate (animal vs non animal) in each site using the non-parametric Kruskal-Wallis and Wilcoxon tests, respectively.

In order to identify taxa representative of the epizoic habitat, the indicator value (IndVal) method (Dufrêne and Legendre, 1997) was used on all data, without abundance threshold. The analysis first focused on all the sites. The group considered was the mixed epizoic samples $(n=5)$, compared to epilithic $(\mathrm{n}=5)$ and epiphytic $(\mathrm{n}=5)$ samples. Then, the analysis was applied to each site, considering all the individual epizoic samples $(\mathrm{n}=7$ or 10$)$, compared to the two non-epizoic samples ( $\mathrm{n}=2$ ).

Differences in the composition of all samples in the study $(n=62)$ were analysed by ascending hierarchical classification using Ward's method and Canberra distance. The resulting dendrogram was cut at two distance levels to highlight relevant groups. At sites where differences between substrates were apparent, the epilithic, epiphytic and mixed epizoic samples were compared on the basis of their composition into functional groups. The assignment of functional groups to species or genera was done according to the classification of taxa proposed by Rimet and Bouchez (2012). Chi-Square tests were carried out to assess in each site and among substrate types (1) the similarity of functional composition of diatom communities and (2) the equality of proportions of some life forms.

\section{RESULTS}

Diatoms were found on the carapaces of all individuals of Emys orbicularis used in the study $(\mathrm{n}=47)$. A total of 375 taxa were identified in the epizoic samples. The absence of macrophytes on the carapaces suggested that these diatoms were directly epizoic and not epiphytic and secondarily epizoic. The diversity and species richness of diatom samples varied significantly among sites $\left(\mathrm{p}<10^{-6}\right)$. There was a significant effect of the type of substrate only

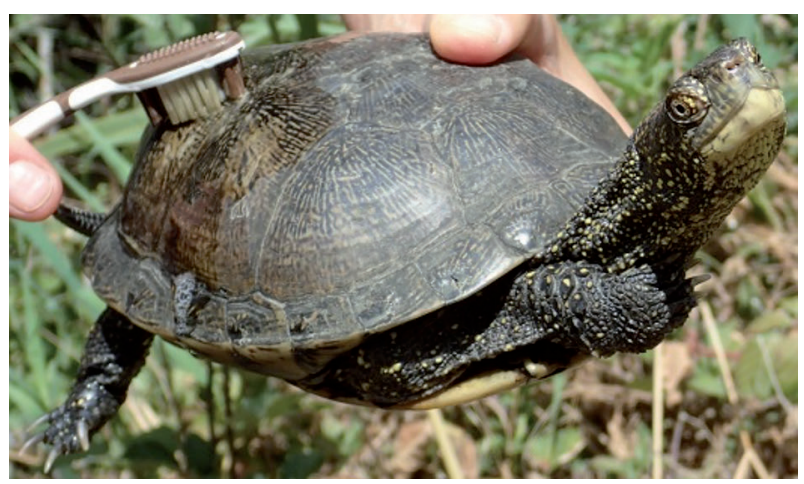

Fig. 2. Sampling of epizoic diatoms on the carapace of an individual of Emys orbicularis.

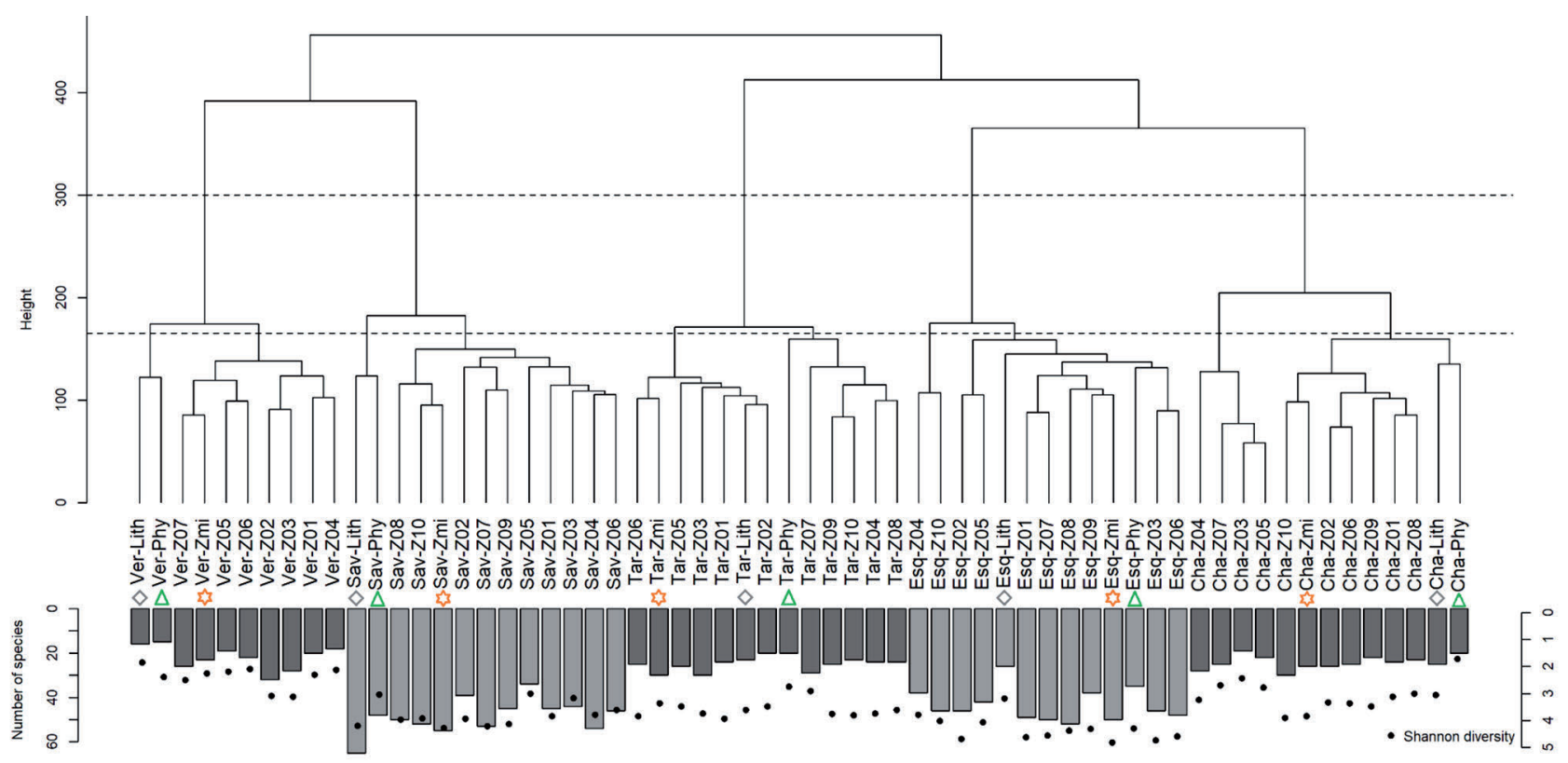

Fig. 3. Dendrogram derived from the ascending hierarchical classification of the 62 diatom samples and barplot of species number with indication of Shannon diversity. The codes 'Lith' and 'Phy' mean epilithic and epiphytic. The code 'Zmi' corresponds to the mixed epizoic sample whereas the codes ' $\mathrm{Z} 01$ ' to ' $\mathrm{Z10}$ ' are for the individual epizoic samples. Stars, diamonds and triangles indicate mixed epizoic, epilithic and epiphytic samples, respectively. 
on species richness and at two sites $(\mathrm{p} \leq 0.05)$. Indeed, epizoic samples were richer in species than non-epizoic samples in the sites Ver and Esq (Fig. 3).

\section{Different epizoic communities among study sites}

Considering the dendrogram resulting from the ascending hierarchical classification, five groups could be clearly distinguished, defined by a cutting level at a distance of 300 (Fig. 3). These five groups corresponded exactly to the five study sites, meaning that the periphytic communities depended more on the water body they came from, than on the type of substrate from which they were extracted. The species richness of the samples was highest at the Esq and Sav sites (40 to 50 species, Fig. 3). The non-parametric multivariate analysis of variance indicated that the epizoic communities of the five sites were significantly different $\left(\mathrm{p}=10^{-4}\right)$ and that the communities at each site differed significantly from those at each of the other sites $\left(\mathrm{p} \leq 210^{-4}\right)$. These differences between the sites were clearly visible in the principal coordinate analysis (Fig. 4) where the sample groups corresponding to the sites were well separated from each other. It can also be seen that the first axis of the PCoA, as well as the first node of the classification tree, separated the Mediterranean sites Tar, Esq and Cha from the two other sites.

\section{The taxa preferring the epizoic habitat}

Analysis of indicator values across sites revealed the preference of only two taxa for the epizoic habitat (Ind$\mathrm{Val}=0.6 ; \mathrm{p} \leq 0.06$, Tab. 2). These are Navicula trivialis and Fallacia pygmaea. The IndVal value of 0.6 resulted from the absence of both species in all epilithic or epiphytic samples and their presence in three out of five mixed epizoic samples. Both species were present at the sites Cha and Esq. Navicula trivialis was also found at Sav and F. pygmaea at Tar.

\section{Intra-site differences between epizoic and non-epizoic communities}

The composition of the epizoic communities differed from that of the epilithic and epiphytic communities in

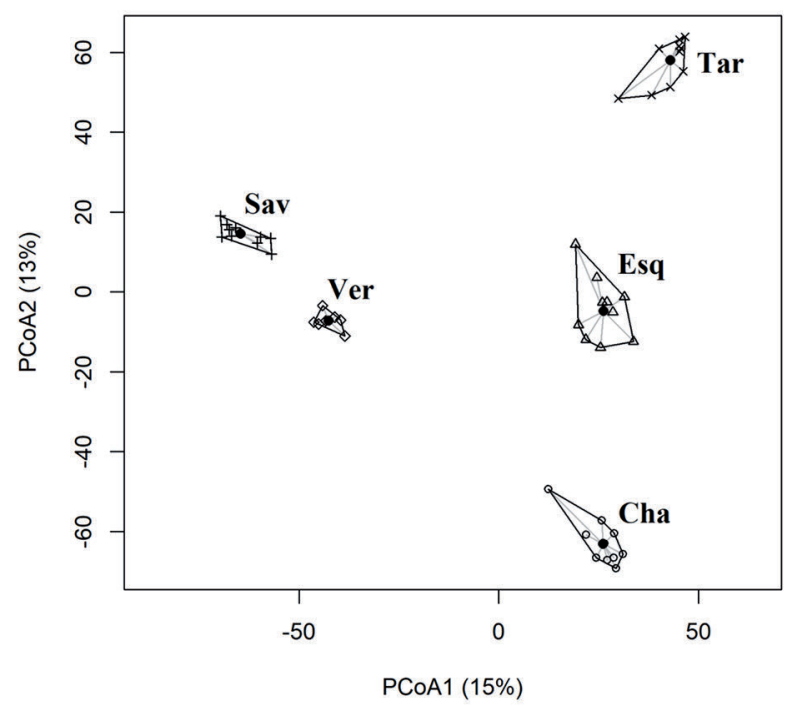

Fig. 4. Plot of the principal coordinate analysis performed on individual epizoic samples $(\mathrm{n}=47)$.

Table 2. Indicator values (IndVal) of species significantly $(\mathrm{p}<0.1)$ associated with the epizoic habitat, at the scale of the five sites and in each site separately.

\begin{tabular}{|c|c|c|c|}
\hline Site & Taxon & IndVal & p-value \\
\hline All sites & $\begin{array}{l}\text { Navicula trivialis Lange-Bertalot } \\
\text { Fallacia pygmaea (Kützing) Stickle \& D.G.Mann in Round et al. }\end{array}$ & $\begin{array}{l}0.6 \\
0.6\end{array}$ & $\begin{array}{l}0.059 \\
0.060\end{array}$ \\
\hline Sav & $\begin{array}{l}\text { Pseudostaurosira brevistriata (Grunow) D.M.Williams \& Round } \\
\text { Staurosirella mutabilis (W.Smith) E.Morales \& Van de Vijver in Morales et al. } \\
\text { Navicula cryptocephala Kützing } \\
\text { Staurosira venter (Ehrenberg) Cleve \& J.D.Möller } \\
\text { Cyclotella distinguenda Hustedt } \\
\text { Staurosira binodis Lange-Bertalot in Hofmann et al. }\end{array}$ & $\begin{array}{l}0.97 \\
0.94 \\
0.90 \\
0.90 \\
0.82 \\
0.80\end{array}$ & $\begin{array}{l}0.018 \\
0.051 \\
0.069 \\
0.071 \\
0.045 \\
0.094\end{array}$ \\
\hline Ver & $\begin{array}{l}\text { Frustulia crassinervia (Brébisson ex W.Smith) Lange-Bertalot \& Krammer } \\
\text { Sellaphora pupula (Kützing) Mereschkowksy } \\
\text { Gomphonema auritum A.Braun ex Kützing } \\
\text { Discostella stelligera } \text { var. tenuis (Hustedt) Houk \& Klee } \\
\text { Aulacoseira pusilla (F.Meister) Tuji \& Houki }\end{array}$ & $\begin{array}{l}0.86 \\
0.86 \\
0.86 \\
0.77 \\
0.68\end{array}$ & $\begin{array}{l}0.086 \\
0.087 \\
0.092 \\
0.021 \\
0.028\end{array}$ \\
\hline Cha & $\begin{array}{l}\text { Cocconeis placentula var. placentula Ehrenberg } \\
\text { Luticola goeppertiana (Bleisch) D.G.Mann ex Rarick, S.Wu, S.S.Lee \& Edlund }\end{array}$ & $\begin{array}{l}0.90 \\
0.88\end{array}$ & $\begin{array}{l}0.059 \\
0.012\end{array}$ \\
\hline Esq & $\begin{array}{l}\text { Bacillaria paxillifera (O.F.Müller) T.Marsson } \\
\text { Navicula trivialis Lange-Bertalot } \\
\text { Tryblionella hungarica (Grunow) D.G.Mann }\end{array}$ & $\begin{array}{l}1.00 \\
0.90 \\
0.97\end{array}$ & $\begin{array}{l}0.016 \\
0.055 \\
0.027\end{array}$ \\
\hline Tar & Navicula veneta Kützing & 0.73 & 0.028 \\
\hline
\end{tabular}


only two of the five sites. A cut in the classification tree at distance 165 separated two groups of samples at each of the sites (Fig. 3). These groups corresponded to substrate type (animal vs mineral/vegetal) at the sites Ver and Sav. At the other sites, substrate type did not seem to be an important factor. However, at the site Cha, non-epizoic communities differed from a group of six epizoic samples but were closer to them than to a group of four other marginal epizoic samples. The analysis of indicator values at these sites revealed a significant ecological preference of some taxa for the animal substrate (Tab. 2). At the site Sav, these taxa were mostly of the Staurosiraceae family. At the sites Sav and Ver, the epizoic habitat was characterized by planktonic species of the genera Discostella, Aulacoseira (Ver) and Cyclotella (Sav). Species of the Bacillariaceae family obtained very high indicator values at the site Esq (Bacillaria paxillifera and Tryblionella hungarica). At each site, some species of Naviculales were also found indicator of turtle communities, such as Navicula cryptocephala (Sav), N. veneta (Tar) or N. trivialis (Esq), or Frustulia crassinervia and Sellaphora pupula (Ver) or Luticola goeppertiana (Cha).

A more detailed analysis of the communities was justified in the two sites where differences between substrates emerged (Ver and Sav). Indeed, the variations in community composition between substrates observed at these two sites led to some discrepancies in the representation of ecological guilds and life forms. However, the patterns were not the same at the two sites. At the site Sav, the functional compositions of diatom communities on stones and plants were similar $(p>0.4)$ whereas the composition of epizoic diatoms differed significantly from them ( $p<10^{-15}$, Fig. 5). There were more 'high profile' guild species in the epizoic communities compared to communities of other substrate types. At the site Ver, the differences were significant between all substrates $\left(p<10^{-6}\right)$. There were more planktonic diatoms on the turtle carapaces $\left(p \leq 10^{-6}\right)$. Considering life forms rather than ecological guilds, both sites had a lower proportion of pioneer diatoms on turtles, which was the only common feature of the epizoic communities at these sites, whereas the site Sav was characterized by more colonial forms and the site Ver by fewer pedunculated forms on turtles (Fig. 6).

\section{DISCUSSION}

Epizoic diatoms were present on the carapace of Emys orbicularis, as previously observed on other freshwater (Donato et al., 2018) and marine (Robinson et al., 2016) turtle species. The numbers of species identified were higher than those reported in previous works (Soylu et al., 2006; Robinson et al., 2016; Wu and Bergey, 2017; Donato et al.,2018). This can be explained by differences in sampling protocols or by the higher diversity of diatoms in the sites explored in this study. While small differences in specific and functional composition could be found between substrates, especially at two sites (Ver and Cha), it appeared that the carapace of the pond turtle did not harbour a consistent, characteristic diatom community.

The differences in composition between the five sites were very significant and were probably due to local ecological factors and biogeographic effects, which in particular linked the three Mediterranean sites (Tar, Esq and Cha). This has to be compared with the study of American populations of another species of freshwater turtle, Chelydra serpentina (Wu and Bergey, 2017). It was found that some epizoic communities of turtle populations, although very distant in space, were not significantly different. The diatoms present on marine turtles provide an even greater contrast to the present study. Indeed, it appeared that marine turtles had on their carapace little diversified and similar diatom communities, whatever the species or the origin of the turtle individuals. Moreover, some taxa were identified as obligatory epibionts (e.g., Poulinea or Chelonicola) (Robinson et al., 2016). Nevertheless, the homogeneity of epizoic diatom communities among turtle populations is not sufficient to demonstrate their specificity to the turtle carapace. It is necessary to examine in parallel the benthic communities present on other substrates in the vicinity of the turtle populations.

At the scale of the five sites in South-Eastern France and among the large number of taxa recorded on the

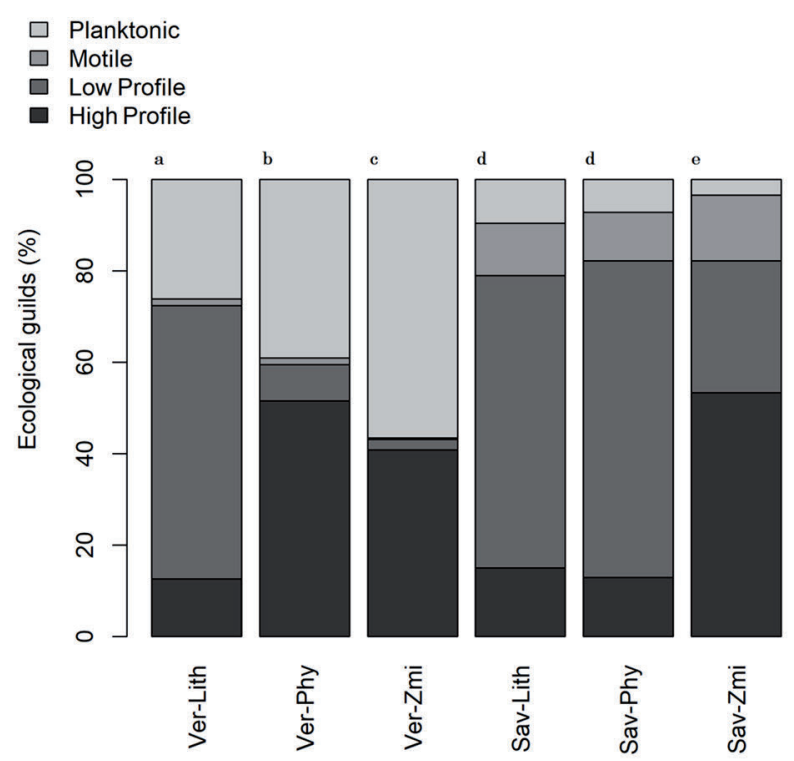

Fig. 5. Proportions of the four diatom ecological guilds in the epilithic, epiphytic and mixed epizoic samples from the sites Ver and Sav (same codes as in Figure 2). The letters above the plot indicate groups of significantly different compositions $(\mathrm{p}<0.05)$. 
pond turtle carapace, only two species were identified as characteristic of the epizoic habitat, while appearing in only three out of five sites (Tab. 2). Navicula trivialis and $F$. pygmaea are however commonly found on a variety of benthic substrates in the framework of aquatic ecosystem monitoring. They cannot be considered as typically epizoic species even though the turtle carapace appears to be a suitable substrate for them. They should be distinguished from the species Luticola deniseae found exclusively on a Brazilian freshwater turtle (Wetzel et al., 2010) and from the marine genera Poulinea and Chelonicola considered as obligate epibionts (Robinson et al., 2016).

Although no specific diatom communities or taxa could be found on the pond turtle carapace, different diatom assemblages on turtles, plants and stones were expected at the same site. Indeed, compared to other substrates, the carapace presents particular characteristics that should select an adapted epizoic community. The mobility of the turtle generates variable light conditions and friction forces with water or objects that the animal comes into contact with. It should also reduce sediment build-up on the carapace. The movements of individuals to other water bodies (Owen-Jones et al., 2015; Fuentes and Olivier, 2016) may introduce new species not present in the sampling site. In addition, certain life history traits of the pond turtle should considerably influence epizoic communities. The turtles' egg-laying out of the water promote exchanges with soil microorganisms. Moreover, the ectotherm turtles get out of the water almost daily in spring to expose themselves to sunlight (basking) and this represents an important pressure on the biofilm of the carapace. It has even been hypothesized that this behaviour allows the turtles to control by desiccation the epizoic algal biomass that can harm their health when algal development becomes excessive (Neil and Allen, 1954). Although it has not been demonstrated, turtles' carapaces may contain chemicals that have antifouling properties (e.g., such as those found in marine sponges; Amsler et al., 2000).

However, turtle carapace communities differed in epilithic and epiphytic communities in only the two most inland sites (Sav and Ver) (Fig. 3). The pattern could have been the same at the site Cha if four marginal epizoic samples had not been taken into account. It was interesting to note the functional implications of the variations in composition between epizoic and non-epizoic substrates (Figs. 5 and 6). The lower proportion of pioneer species suggests a more mature biofilm on turtle carapaces. Although autochthonous mineral substrates were used for sampling at these sites, the age of the biofilm on pebbles or macrophytes may have been reduced by water level fluctuations or plant growth. The higher relative abundance of 'high profile' colonial and a

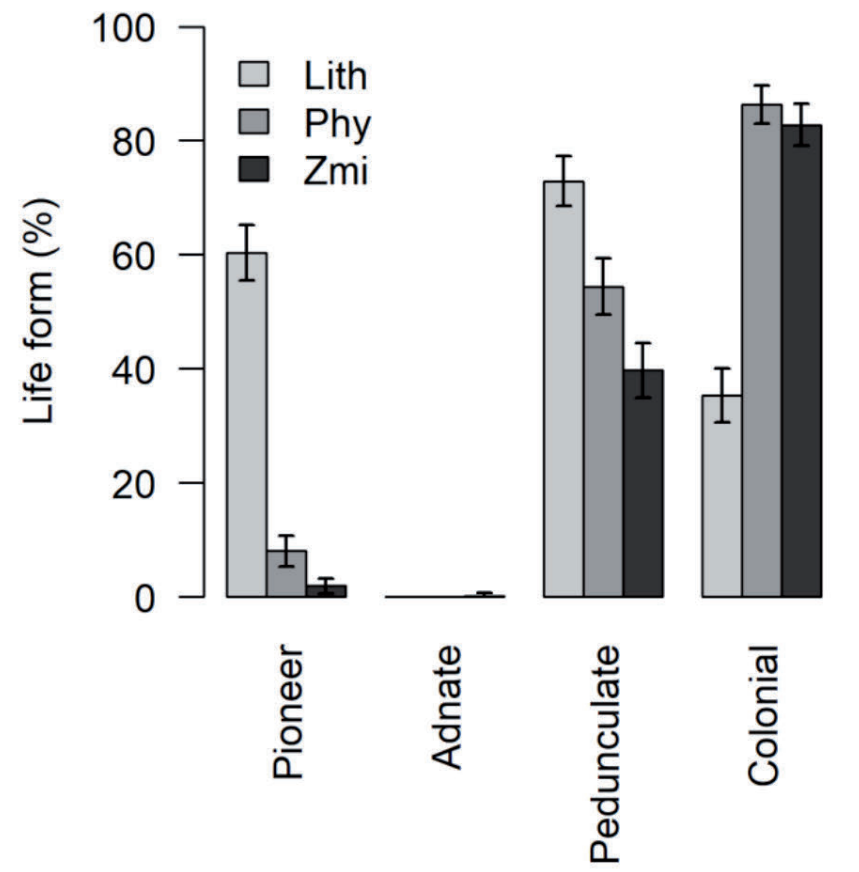

b

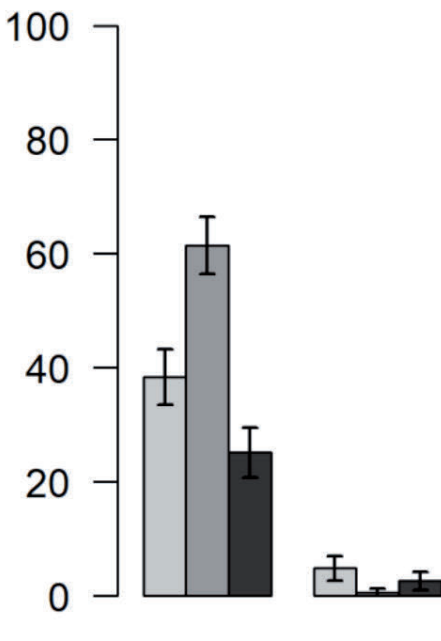

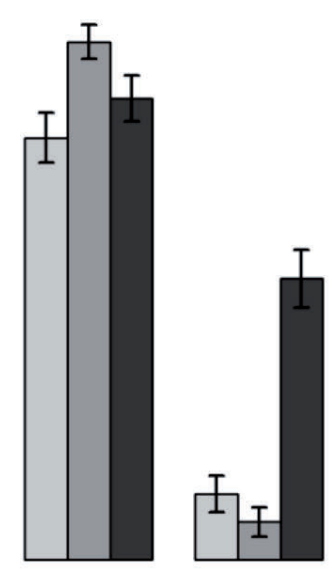

$\frac{1}{\pi}$
$\frac{0}{3}$
$\frac{0}{5}$
$\frac{1}{0}$
0

Fig. 6. Proportions of the main life forms of periphytic diatoms in the epilithic (Lith), epiphytic (Phy) and mixed epizoic (Zmi) samples from the sites Ver (a) and Sav (b). (note: the same species may belong to two different groups). Errors bars indicate $95 \%$ confidence intervals. 
planktonic (unattached) species and the lower representation of pedunculated species suggest living conditions with less turbulence or abrasive forces (Passy, 2007), perhaps distant from nearshore area where epilithic and epiphytic communities were collected.

Furthermore, the preponderance of planktonic forms indicates a deeper living environment where planktonic diatoms are more numerous and are deposited on benthic substrates. The observed differences in composition could therefore be explained by the frequentation by the turtles of deeper areas of the water body than those where stones and plants were found for sampling. Other studies have shown quite different distributions of diatom life forms attached to turtles. In the study of seven freshwater turtle species, a common feature of epibiotic diatoms was the quasi absence of solitary species in favour of colonial forms (Donato et al., 2018), while in the study of seven marine turtle species, adnate forms were dominant (Robinson et al., 2016). Although differences with other substrates were found for the sites Sav and Ver, there is apparently no universal functional community profile characterizing the turtle epizoic habitat.

Even if the compositions of the epizoic and non-epizoic communities were consistently not very different (case of the Cha, Tar and Esq sites), the analysis of the indicator values could reveal certain taxa preferentially associated with turtle carapaces. It should be noted that no indicator taxon of epizoic habitat was common to two different sites (Tab. 2). It therefore seems unlikely that an obligate epibiont could be found among the indicator species identified, especially since most of these species are common on other substrates or in the water column, in the case of planktonic diatoms (sites Sav and Ver). They are therefore facultative epibionts having found favourable conditions on the pond turtle carapace or surviving there until accessing other habitats. However, recent literature on diatoms attached to turtles draws attention to a particular taxon, listed as an indicator in the site Cha: Luticola goeppertiana (Tab. 2). This species reached a relative abundance of $9 \%$ in the mixed epizoic sample from the site. The genus Luticola was the subject of particular interest in two studies dealing with diatom-turtle relationships in freshwater. A new species, L. deniseae, was discovered on the carapace of the turtle species Podocnemis erythrocephala in Brazil, with which it appeared to be specifically associated excluding other substrates (Wetzel et al., 2010). In the USA, two Luticola species were found dominant on all carapaces of the turtle Chelydra serpentina, with a preponderance of Luticola cf. goeppertiana (Wu and Bergey, 2017). It therefore seems that the genus Luticola is particularly adapted to turtle carapaces, perhaps because of its resistance to desiccation (Wu and Bergey, 2017). The closest widespread species to $L$. deniseae is $L$. goeppertiana
(Wetzel et al., 2010). Further taxonomic analysis of $L u$ ticola species found on carapaces may indicate whether L. deniseae is an obligate epibiont of freshwater turtles that may occur on different host species across continents.

\section{CONCLUSIONS}

Overall, the epizoic diatom communities on the carapace of Emys orbicularis identified at all five study sites are not specific, as they appear strongly influenced by the environment close to the turtles and are not or hardly distinguishable from the surrounding epilithic or epiphytic communities. This is consistent with the concept of facultative epibiosis (Wahl and Mark, 1999). At some sites, differences in specific and functional composition from mineral and plant substrates were observed, probably due to turtle-specific characteristics, such as those associated with their behaviour. However, these differences were site-specific and were not sufficient to demonstrate a general trend in the selection of taxa on turtle carapaces. At the species level, it was difficult to find taxa preferring epizoic habitat at the scale of the five sites. The carapace of the European pond turtle can be considered relatively neutral and could be used for sampling periphytic diatoms as well as stones or macrophytes for bioindication of water quality (Vassal et al., 2020). This appears to be less the case for the American species Chelydra serpentina (Wu and Bergey, 2017) and even less for marine turtle species (Robinson et al., 2016). In the marine environment, the habitat of a turtle species, either neritic or pelagic, probably influences the specificity of the epizoic communities compared to the periphyton which covers the closest benthic substrates (Frick and Pfaller, 2013). Similarly, in freshwater environments, the contact of a species with other substrates in the euphotic zone and the contact of individuals with each other might be important drivers.

\section{ACKNOWLEDGMENTS}

We are indebted to the many people who participated in the turtle catches, in particular Maëlys Marage (Tour du Valat), Rozen Rocher and Cédric Roy (CEN PACA), Olivier Scher (CEN LR), Joanny Piolat (Association Lo Parvi), Florian Véron and Magalie Rambourdin (CEN Allier). We thank the French Ministry of Environment for giving us the permission to capture European pond turtles at all sampling sites. This study was made possible thanks to the support of Séverine Lopez and the management of the Service Biodiversité Eau et Paysage of the DREAL PACA. We would like to express our sincere thanks to them. 
Corresponding author: vincent.roubeix@ifremer.fr.

Present address: Ifremer - RBE/BE, Rue de l'Ile d'Yeu, BP 21105, 44311 Nantes Cedex 03, France

Keywords: Emys orbicularis; epizoic habitat; microalgae; selection; specificity.

Received: 11 October 2020.

Accepted: 7 February 2021.

This work is licensed under a Creative Commons Attribution NonCommercial 4.0 License (CC BY-NC 4.0).

${ }^{\circ}$ Copyright: the Author(s), 2021

Licensee PAGEPress, Italy

Advances in Oceanography and Limnology, 2021; $12: 9119$

DOI: 10.4081/aiol.2021.9119

\section{REFERENCES}

Akgul R, Caprazli T, Turker N, Erduğan H, Tosunoğlu M, 2014. Epizoic algae on Emys orbicularis (LINNAEUS, 1758), and Mauremys rivulata (VALENCIENNES, 1833), in the Kayak River Delta (Saros Bay, Turkey) (Testudines: Emydidae, Geoemydidae). Herpetozoa 27:21-28.

Amsler CD, Moeller CB, McClintock JB, Iken KB, Baker BJ, 2000. Chemical defenses against diatom fouling in Antarctic marine sponges. Biofouling 16:29-45. Doi: 10.1080/ 08927010009378428

Anderson MJ, 2001. A new method for non-parametric multivariate analysis of variance. Austral Ecol. 26:32-46. Doi: 10.1111/j.1442-9993.2001.01070.pp.x

Biggs BJF, Stevenson RJ, Lowe RL, 1998. A habitat matrix conceptual model for stream periphyton. Arch. Hydrobiol. 143:21-56. Doi: 10.1127/archiv-hydrobiol/143/1998/21

Blindow I, 1987. The composition and density of epiphyton on several species of submerged macrophytes - the neutral substrate hypothesis tested. Aquat. Bot. 29:157-168. Doi: 10.1016/0304-3770(87)90093-3

Cadi A, Nemoz M, Thienpont S, Joly P, 2008. Annual home range and movement in freshwater turtles: management of the endangered European pond turtle (Emys orbicularis). Rev. Esp. Herp. 22:71-86.

Di Trani C, Zuffi MAL, 1997. Thermoregulation of the European pond turtle Emys orbicularis, in central Italy. Chelonian Conserv. Biol. 2:428-430.

Donato J, González-Trujillo J, Romero B, Castro Rebolledo M, 2018. Diatom assemblages associated with turtle carapaces in the Neotropical region. Rev. Biol. Trop. 66:1362-1372. Doi: $10.15517 /$ rbt.v66i4.31396

Dufrêne M, Legendre P, 1997. Species assemblages and indicator species: the need for a flexible asymmetrical approach. Ecol. Monogr. 67:345-366. Doi: 10.1890/00129615(1997)067[0345:SAAIST]2.0.CO;2

Edgren RA, Edgren MK, Tiffany LH, 1953. Some North American turtles and their epizoophytic algae. Ecology 34:733740. Doi: $10.2307 / 1931336$

Ersanli ET, Gonulol A, 2014. Epizoophyte composition on spotted turtle Emys orbicularis (Linnaeus, 1758) in Turkey.
Bangladesh J. Bot. 43:157-161. Doi: 10.3329/bjb.v43i2. 21667

Fayolle S, Moriconi C, Oursel B, Koenig C, Suet M, Ficheux S, Logez M, Olivier A, 2016. Epizoic algae distribution on the carapace and plastron of the European pond turtle (Emys orbicularis, Linnaeus, 1758): A study from the Camargue, France. Cryptogamie Algol. 37:221-232. Doi: 10.7872/crya/ v37.iss4.2016.221

Frick M, Pfaller J, 2013. Sea turtle epibiosis, p. 399-426. In: J. Wyneken, K.J. Lohman, and J.A. Musick (eds.), The biology of sea turtles. Boca Raton.

Fuentes T, Olivier A, 2016. Movement records of the European pond turtles (Emys orbicularis) in the Camargue (southern France). Tour du Valat.

Irstea, 2013. [Protocole d'échantillonnage des communautés de phytobenthos en plans d'eau. Mise en œuvre de la Directive Cadre Européenne sur l'eau pour les plans d'eau].[in French]. Irstea, Bordeaux. Available from: https://hydrobiodce.inrae.fr/telecharger/phytobenthos-plans-deau/

Lange-Bertalot H, Hofmann G, Werum M, Cantonati M, 2017. Freshwater benthic diatoms of Central Europe: Over 800 common species used in ecological assessment. English edition with updated taxonomy and added species. Koeltz Botanical Books, Schmitten-Oberreifenberg: 942 pp.

Majewska R, Santoro M, Bolaños F, Chaves G, De Stefano M, 2015. Diatoms and other epibionts associated with Olive ridley (Lepidochelys olivacea) sea turtles from the Pacific coast of Costa Rica. PLoS One 10:1-15. Doi: 10.1371/journal.pone.0130351

Majewska R, Robert K, Van de Vijver B, Nel R, 2020. A new species of Lucanicum (Cyclophorales, Bacillariophyta) associated with loggerhead sea turtles from South Africa. Bot. Lett. 167:7-14. Doi: 10.1080/23818107.2019.1691648

Naulleau G, 1992. Study of terrestrial activity and aestivation in Emys orbicularis (Reptilia, Chelonia) using telemetry, p. 343-346. In: Z. Korsos and I. Kiss (eds.), Proceedings of the 6 th ordinary general meeting of the Societas Europaea Herpetologica, Budapest.

Neil WT, Allen ER, 1954. Algae on turtles: some additional considerations. Ecology 35:581-584. Doi: 10.2307/1931051

Oksanen J, Blanchet FG, Friendly M, Kindt R, Legendre P, McGlinn D, Minchin PR, O'Hara RB, Simpson GL, Solymos P, Stevens MHH, Szoecs E, Wagner H, 2019. vegan: Community Ecology Package. R package version 2.5-4.

Owen-Jones Z, Priol P, Thienpont S, Cheylan M, Sauret G, Coïc C, Besnard A, 2015. The contrasting effects of short- and long-term habitat drainage on the population dynamics of freshwater turtles in a human-dominated landscape. Freshwater Biol. 61:121-132. Doi: 10.1111/fwb.12687

Passy SI, 2007. Diatom ecological guilds display distinct and predictable behavior along nutrient and disturbance gradients in running waters. Aquat. Bot. 86:171-178. Doi: 10.1016/ j.aquabot.2006.09.018

Poulíčková A, Manoylov K, 2019. Ecology of freshwater diatoms - Current trends and applications, p. 289-309. In: J. Seckbach and R. Gordon (eds.), Diatoms: Fundamentals and Applications. John Wiley \& Sons, Ltd. DOI: 10.1002/ 9781119370741.ch13

Rhodin AG, Stanford CB, van Dijk PP, Eisemberg C, Luiselli L, Mittermeier RA, et al, 2018. Global conservation status 
of turtles and tortoises (Order Testudines). Chelonian Conserv. Biol. 17:135-161. Doi: 10.2744/CCB-1348.1

Rimet F, Bouchez A, 2012. Life-forms, cell-sizes and ecological guilds of diatoms in European rivers. Knowl. Manag. Aquat. Ec. 406:1. Doi: 10.1051/kmae $/ 2012018$

Roberts DW, 2019. labdsv: Ordination and multivariate analysis for ecology.

Robinson NJ, Majewska R, Lazo-Wasem EA, Nel R, Paladino FV, Rojas L, Zardus JD, Pinou T, 2016. Epibiotic diatoms are universally present on all Sea turtle species. PLoS One 11:1-8. Doi: 10.1371/journal.pone.0157011

Rovero F, Chelazzi G, 1996. Nesting migrations in a population of Emys orbicularis (L.) (Chelonia Emydidae) from central Italy. Ethol. Ecol. Evol. 8:297-304. Doi: 10.1080/ 08927014.1996.9522920

Soylu E, Gönülol A, Sukatar A, Ayaz D, Tok C, 2006. Epizoic Freshwater Algae on Emys orbicularis (Testudinata: Emydidae) from the Central Anatolia Region of Turkey. J. Freshwater Ecol. 21:535-538. Doi: 10.1080/02705060.006. 9665033

Thienpont S, 2020. Plan National d'Actions en faveur de la Cistude d'Europe (Emys orbicularis) 2020-2029. Société Herpétologique de France. Ministère de la Transition Ecologique. $103 \mathrm{pp}$.

Vassal V, Ector L, Van de Vijver B, Roubeix V, Olivier A, Pauvert S, Roy C, Fayolle S, 2020. Pond turtle carapaces, an alternative natural substrate for the use of a diatom-based water qual- ity index. Bot. Lett. Doi: 10.1080/23818107.2020.1724825

Vidakovic D, Dimitrijevic J, Krizmanic I, Krizmanic J, 2018. Diatoms on the carapace of European pond turtle (Emys orbicularis) in Vojvodina. Proceedings of the VII Balkan Botanical Congress, Novi Sad.

Wahl M, 1989. Marine epibiosis. I. Fouling and antifouling: some basic aspects. Mar. Ecol. Prog. Ser. 58:175-189. Doi: 10.3354/MEPS058175

Wahl M, 2008. Ecological lever and interface ecology: epibiosis modulates the interactions between host and environment. Biofouling 24:427-438. Doi: 10.1080/08927010802339772

Wahl M, Mark O, 1999. The predominantly facultative nature of epibiosis: experimental and observational evidence. Mar. Ecol. Prog. Ser. 187:59-66. Doi: 10.3354/meps187059

Wetzel CE, Van de Vijver B, Ector L, 2010. Luticola deniseae sp. nov. A new epizoic diatom from the Rio Negro (Amazon hydrographic basin). Vie Milieu 60:177-184.

Wetzel CE, Van de Vijver B, Cox EJ, Bicudo DC, Ector L, 2012. Tursiocola podocnemicola sp. nov., a new epizoic freshwater diatom species from the Rio Negro in the Brazilian Amazon Basin. Diatom Res. 27:1-8. Doi: 10.1080/0269249X. 2011.642498

Wu SC, Bergey EA, 2017. Diatoms on the carapace of common snapping turtles: Luticola spp. dominate despite spatial variation in assemblages. PLoS One 12:e0171910. Doi: 10.1371/ journal.pone. 0171910 